\title{
REHABILITATION OF PATIENTS WITH INFERIOR ALVEOLAR NERVE INJURIES
}

\author{
Kopetsky IS ${ }^{1}$, Eremin DA', Polunina NV², Polunin VS² ${ }^{2}$, Buslaeva $\mathrm{GN}^{2}$, Khetagurova $\mathrm{AK}^{2}$ \\ Department of Dental Therapy, Faculty of Dentistry \\ Pirogov Russian National Research Medical University, Moscow \\ 2 Department of Public Health, Healthcare and Healthcare Economics, Faculty of Pediatrics, Pirogov Russian National Research Medical University, Moscow
}

\begin{abstract}
Mandibular fractures are a common type of injuries of the facial bones. Most of them affect the angle and body of the mandible in the areas innervated by the inferior alveolar nerve (IAN). Inpatients of maxillofacial units often lack health literacy; therefore, the aim of our study was to improve the effect of treatment in patients with mandibular fractures and IAN injuries by motivating patients toward a healthy lifestyle and by pioneering the use of therapeutic agents Mexicor and Combilipen in the standard regimen.
\end{abstract}

Keywords: mandibular fracture, inferior alveolar nerve injury, rehabilitation, healthy lifestyle, Mexicor, Combilipen

Correspondence should be addressed: Valery Polunin

Ostrovityanova 1, Moscow, 117997; lunapol@yandex.ru

Received: 14.11.2017 Accepted: 16.02.2018

DOI: $10.24075 / \mathrm{brsmu} .2018 .007$

\section{РАЗРАБОТКА МЕРОПРИЯТИЙ ПО РЕАБИЛИТАЦИИ ПАЦИЕНТОВ С ПОВРЕЖДЕНИЕМ НИЖНЕГО АЛЬВЕОЛЯРНОГО НЕРВА}

\author{
И. С. Копецкийㄱ, Д. А. Еремин ${ }^{1}$, Н. В. Полунина², В. С. Полунин ${ }^{2}$, Г. Н. Буслаева², А. К. Хетагурова ${ }^{2}$
}

\author{
Кафедра терапевтической стоматологии, стоматологический факультет \\ Российский национальный исследовательский медицинский университет им. Н. И. Пирогова, Москва \\ ${ }^{2}$ Кафедра общественного здоровья и здравоохранения, экономики здравоохранения, педиатрический факультет \\ Российский национальный исследовательский медицинский университет им. Н. И. Пирогова, Москва,
}

\begin{abstract}
Среди повреждений костей лицевого скелета переломы нижней челюсти встречаются часто. Наиболее распространенной локализацией переломов нижней челюсти при которых происходит травма нижнего альвеолярного нерва (НАН), являются угол и тело, в толще которых проходит НАН. Пациенты челюстно-лицевых стационаров имеют низкую медицинскую и социальную грамотность, поэтому целью исследования явилось повышение эффективности лечения больных с переломами нижней челюсти, сопровождающимися травмой НАН, путем внедрения нового комплекса фармакологических препаратов - Мексикора и Комбилипена, ранее не использовавшихся в челюстнолицевой хирургии, и медико-социальных мероприятий, направленных на формирование мотивации к ведению здорового образа жизни у пациентов.
\end{abstract}

Ключевые слова: перелом нижней челюсти, повреждение нижнего альвеолярного нерва, социальная реабилитация, здоровый образ жизни, Мексикор, Комбилипен

$\triangle$ Для корреспонденции: Полунин Валерий Сократович

ул. Островитянова, д. 1, г. Москва, 117997; lunapol@yandex.ru

Статья получена: 14.11.2017 Статья принята к печати: 16.02.2018

DOI: $10.24075 /$ vrgmu.2018.007

In recent years, severe traumatic injuries of facial bones have become increasingly incident, including multiple fractures and associated injuries received in road accidents, assaults, sports competitions, etc. [1]. According to foreign and domestic reports, mandibular fractures make up to $87 \%$ of such injuries; most of them involve damage to the inferior alveolar nerve (IAN) $[2,3]$ caused by bruising, overstretching or pressure from the fragments of the injured mandible. Strains are observed in $70.1 \%$ of cases, contusion in $16.8 \%$, incomplete rupture in $12.5 \%$, and complete rupture in $0.6 \%$ of cases [4]. IAN injuries are subdivided into subclinical, mild, moderate, moderateto-severe, and severe [5, 6]. Regardless of their type, they trigger neurotrophic changes in all tissues innervated by IAN, resulting in poor bone healing and sensory deficit. One of the major symptoms of IAN damage suffered by every patient is pain $[7,8]$. Inpatient care is normally provided at maxillofacial units; outpatients are referred to special rehabilitation units upon discharge from hospital. Treatment includes surgical interventions, such as immobilization of fractured bones or external fixation if bones are severely displaced, and conservative drug therapies $[9,10,11,12,13]$.

Management of mandibular fractures should also include psychological counselling to motivate patients towards a healthy lifestyle and health literacy $[14,15]$. 
Delayed diagnosis, immobilization or surgical intervention, ineffective therapy, failure to comply with doctor's recommendations and unwillingness to give up bad habits lead to the irreversible damage to IAN, which ultimately impedes fracture healing, promotes inflammation, and causes the loss of sensation and muscle dysfunction in the affected zone. Therefore, there is a need for an improved rehabilitation plan for patients with mandibular fractures.

\section{METHODS}

The study recruited 212 men aged 19 to 63 with unilateral mandibular fractures and no severe comorbidities who presented to Pirogov City Clinical Hospital No. 1 (Moscow) in 2011-2016 within 24 hours after the injury. Patients with severe comorbidities, inflammation, and multiple fractures of the mandible were excluded from the study. All the participants gave their informed consent. The study was approved by the Ethics Committee of Pirogov Russian National Research Medical University (Protocol No. 107 dated April 18, 2011). The participants were surveyed to obtain information about their medical history and social background. Upon discharge from the hospital the patients were referred to the rehabilitation unit. The patients also received psychological counseling.

Generally, treatment included fracture immobilization and extraction of teeth in the fracture line, if indicated. If brain injury was suspected, the patients were referred to a neurologist or a neurosurgeon. Possible comorbidities were ruled out by a primary care physician, trauma surgeon, and otolaryngologist. If maxillomandibular fixation turned out to be ineffective or the patients developed posttraumatic malocclusion, titanium plate osteosynthesis was performed. Conservative therapy included antibiotics to prevent inflammatory complications (IM injections of $2 \mathrm{ml}$ lincomycin and $1 \mathrm{~g}$ cefazolin, both twice a day), analgesics (2 $\mathrm{ml}$ diclofenac, IM, twice a day), oral irrigations, and medications prescribed by other specialists.

The patients were divided into 2 groups. The control group (86 patients) received $1 \mathrm{ml}$ 0.5\% neostigmine methyl sulfate solution (marketed as Proserin by Dalhimfarm, Russia) for one month, 500-1,000 $\mu \mathrm{g}$ cyanocobalamin alternated with $3 \mathrm{ml} 5 \%$ thiamine chloride (15 to 20 injections), and $0.005 \mathrm{~g}$ dibazol per os for one month. The main group consisted of 126 patients who received Combilipen by Pharmstandard-UfaVITA, Russia (pyridoxine + thiamine + cyanocobalamin + lidocaine) and ethyl methyl hydroxypyridine succinate (marketed as Mexicor, EcoPharmlnvest, Russia).

The dose of ethyl methyl hydroxypyridine succinate recommended by the manufacturer was $150 \mathrm{mg}$; it was administered to the patients intramuscularly twice a day for 14 days. After that the patients received the medication in capsules (100 mg twice a day for 21 day).

Combilipen was administered to the patients intramuscularly at the dose of $2 \mathrm{ml}$ once a day for 10 days, followed by a 3-week regimen of 3 times a week.

Based on the classification of IAN injuries proposed by A.Korzh in 1989, the patients in both groups were subdivided into three subgroups depending on whether their IAN injuries were mild, moderate or moderate-to severe/severe.

Treatment effect was evaluated based on:

1. The electrical excitability of the lower lip and chin on the affected side. To measure it, we needed to determine the actual site of nerve damage and estimate its size.

To ensure maximum accuracy of both measurements and result interpretation, we selected three landmarks on the patient's face two of which were located midway between the lower lip and the most prominent point of the chin $(A)$ and midway between the mouth corner and the lower border of the mandible (B). Thus, the line connecting $A$ and $B$ was horizontal. Point $C$ was located halfway between the middle of the lower lip and the mouth corner. The vertical line going downwards from point $\mathrm{C}$ crossed the horizontal line and thus formed 4 test zones [16].

The sensory exam included light stimulation of the chin skin with a brush or a cotton pad. To assess patient's deep sensations, the chin was palpated.

Electrical excitability of the skin on the affected side was measured in the 4 zones mentioned above within 24 hours after admission, on day 10, on days 32-40, after the splints were removed, and 6 months after the injury.

The skin of the examined zones was cleansed with $70 \%$ ethyl alcohol (ethyl alcohol also ensured better electrical conductivity). The electrode of PARKELL Digitest 2 (Parkell, USA) was placed on the sites innervated by IAN in the 4 studied zones. We determined the minimum current that evoked a sensation in the patient (tingling, prickling, etc.). The patient reported their sensation to the doctor. The current was supplied in pulses increasing from 0 to $160 \mu \mathrm{A}$ [17].

Skin excitability on the affected side corresponded with the severity of injuries to IAN aiding the distribution of patients into the groups. For uniformity, skin excitability was measured in zone 3 in all patients. On the intact side it varied from 25 to $35 \mu \mathrm{A}$ in all patients. In patients with mild injuries excitability on the affected side ranged from 35 to $69 \mu \mathrm{A}$; patients with moderate injuries demonstrated a range between 70 and $129 \mu \mathrm{A}$; in patients with severe injuries skin excitability was $130 \mu \mathrm{A}$ and higher.

2. Social background and hygiene of the patients.

More than half of the patients with mandibular fractures were under the influence of alcohol at the time of admission. Of those patients who were behind the wheel during the accident, $29.8 \%$ were drunk. Our survey revealed that $38.4 \%$ of the participants had a drinking problem. There were 2.3 times more alcohol abusers among the unemployed patients than among those who had a job (56.6\% vs $24.6 \%)$. Among the patients with a university degree the number of alcohol abusers was significantly lower $(p<0.05)$ than among those who did not have a degree. The coefficient $r$ of correlation between alcohol abuse and education was $-0.889(m= \pm 0.114, p<0.05)$. Of all surveyed patients, $70.4 \%$ were regular smokers; half of them (50.8\%) admitted that smoking was bad for their health but could not give it up. Only 3.4\% did not believe smoking could have a negative effect on their health.

Ninety percent of the respondents reported that they had never tried narcotic drugs; $7.1 \%$ had tried them once, and $1.9 \%$ still used them occasionally. One in 100 patients was a regular user. All of those patients were below 40 years of age.

Among the patients with mandibular fractures $44.2 \%$ were overweight. Only $13.4 \%$ of the participants watched their weight. Overweight and its metabolic consequences can delay bone healing. A very thick subcutaneous tissue layer complicates palpatory and visual examination of fractures and facial deformities. Sometimes blood vessels leak fluid into the subcutaneous tissue, causing hematomas that can get infected and start festering. In our study the coefficient $r$ of correlation between these parameters was +0.749 ( $n= \pm 0.114, \quad p<0.05)$. Only $9.8 \%$ of patients followed doctor's advice and watched their diet. Among them the majority were over 50 years of age.

Body weight may be indicative of a particular diet a patient follows and his/her attitude to physical exercise. More than 
half of the study participants (59.8\%) tended not to engage in physical activity. Among them the number of patients over 50 years of age was 2.3 times higher than among their younger counterparts $(74.4 \%$ vs $31.1 \%, p<0.05)$. It total, three quarters of the patients rarely visited a doctor when they got ill, did not undergo regular checkups, did not do any therapeutic exercise or follow doctor's advice, etc.

\section{RESULTS}

Using PARKELL Digitest 2 (Parkell, USA) we obtained data about the electrical excitability of the skin in IAN-innervated areas located on the chin and the lower lip. Dental pulp tests were not performed because patients were wearing fixation splints at that moment.

Our study was conducted in two groups of patients: the first consisted of patients with angle fractures of the mandible who received Mexicor and Combilipen as part of their complex therapy, and the second group included patients who did not receive those medications. Measurements were taken on the day of admission, on day 10 following the admission, days 32-40 and 6 months after the injury.

Skin excitability was higher in zones 2 and 3 than in zones 2 and 4.

In patients with mild injuries to IAN mean excitability values were $55 \pm 1.5 \mu \mathrm{A}$ and $58 \pm 1.5 \mu \mathrm{A}$ (zones 2 and 3 , respectively). The patients reported a tingling sensation in the lower lip on the affected side and a reduced sense of touch. In patients with moderate injuries skin excitability varied from $109.6 \pm 3.1 \mu \mathrm{A}$ to $121.9 \pm 3.5 \mu \mathrm{A}$. In patients with severe injuries it ranged from $159.5 \pm 4.5 \mu \mathrm{A}$ to $168.1 \pm 4.8 \mu \mathrm{A}$, suggesting a more serious loss of sensation in the studied zones. Patients with moderate and severe damage to IAN reported a total loss of sensation in these zones, complained of pain, dysfunction of facial muscles, impaired mucosal and dental sensation on the affected side. Because IAN branches supply sensation to the front teeth, small contralateral zones of paresthesia were observed in the lower lip and chin of $18.6 \%$ of patients.

Over the course of treatment, the main group patients with mild injuries demonstrated reduction in skin excitability in zones 1 and $4(29.4 \pm 1.4 \mu \mathrm{A}$ and $27.4 \pm 1.5 \mu \mathrm{A}$, respectively). These values correlated with the electric excitability of the skin on the intact side. In zones 2 and 3 excitability decreased to $40.1 \pm$ $4.2 \mu \mathrm{A}$ and $42.3 \pm 4.0 \mu \mathrm{A}$, respectively, in the main group. This tendency was less pronounced in the controls in which skin excitability decreased to $35.1 \pm 1.4 \mu \mathrm{A}$ in zone $1,49.6 \pm 4.6 \mu \mathrm{A}$ in zone 2, $50.8 \pm 4.6 \mu \mathrm{A}$ in zone 3 , and $36.2 \pm 1.6 \mu \mathrm{A}$ in zone 4 .

In the main group the patients with moderate and severe injuries also demonstrated reduction in the electric excitability of the skin on the affected side. The values were 1.2-1.3 times lower than in the controls.

Our analysis reveals that after completing their treatment, the patients with mild injuries both in the main and control groups had the same level of skin excitability on the affected and intact sides. Only $15 \%$ of the controls retained a tingling sensation, while others no longer showed any clinical symptoms of IAN damage.
In the patients with moderate injuries skin excitability was the highest in zones 2 and 3 , equaling on average $40.5 \pm$ $3.9 \mu \mathrm{A}$ and $59.7 \pm 3.7 \mu \mathrm{A}$, respectively, in the main group, and $65.1 \pm 5.4 \mu \mathrm{A}$ and $85.7 \pm 5.1 \mu \mathrm{A}$, respectively, in the controls. In the main group the paresthetic area grew smaller, but in 25\% of the controls its size did not change.

In the patients with severe damage to IAN, skin excitability in the studied zones was 1.3-1.4. times lower than in the controls. At the end of the treatment course $73 \%$ of the controls still had pronounced clinical symptoms indicating IAN damage, whereas the patients in the main group were gradually improving (smaller areas of paresthesia, less severe pain). As seen from the measurements taken on days 32-40 of treatment, skin excitability in all 4 zones was decreasing in the patients who had been receiving Combilipen and Mexicor. The choice of those therapeutic drugs was not random: Order $1497 n$ of the Ministry of Health of the Russian Federation on the Treatment of patients with damage to the facial nerve dated December 24, 2012, recommends that such patients should be prescribed vitamins B1, B6 and B12 as part of their complex treatment. The beneficial effect of antioxidants in the complex therapy of peripheral nerve injuries has also been demonstrated by a number of foreign and Russian researchers [18, 19].

Rehabilitation of patients with mandibular fractures included psychological counselling, drug therapy and surgical interventions. Only half $(47.7 \%)$ of the patients complied with medical recommendations, $32.7 \%$ ignored those recommendations and $19.6 \%$ followed them selectively.

According to the patients, among the factors interfering with their medical rehabilitation were the absence of positive effect of treatment (49.3 cases), queues in rehab units (41.2), pain or unpleasant sensations during medical procedures (38.7), lack of money (37.6), lack of motivation (28.4), lack of trust in doctors (23) (cases are specified per 100 surveyed patients). Almost half of the surveyed patients who only partially complied with the medical recommendations named 2 to 3 reasons that prevented them from completing the full course of treatment.

\section{DISCUSSION}

The electrical excitability of the skin in the areas innervated by IAN measured at the time of admission was $55.5 \pm 1.5 \mu \mathrm{A}$ in zone 2 and $58 \pm 1.5 \mu \mathrm{A}$ in zone 3 in the patients with mild injuries; in the patients with moderate injuries the figures were $109.6 \pm 3.1 \mu \mathrm{A}$ and $121.9 \pm 3.5 \mu \mathrm{A}$, respectively; in the patients with severe injuries skin excitability in zones 2 and 3 was as high as $159.5 \pm 4.5 \mu \mathrm{A}$ and $168.1 \pm 4.8 \mu \mathrm{A}$, respectively. Ten days after the injury skin excitability decreased 1.2-1.3-fold in the main group in comparison with the controls. On days 32-40 excitability in zones 2 and 3 was $40.5 \pm 3.9 \mu \mathrm{A}$ and $59.7 \pm 3.7 \mu \mathrm{A}$, respectively, in the main group patients with moderate injuries, and $65.1 \pm 5.4 \mu \mathrm{A}$ and $85.7 \pm 5.1 \mu \mathrm{A}$, respectively, in the controls. In the patients with severe injuries it was 1.3-1.4 times lower than in the controls. $73 \%$ of the controls retained clinical symptoms at the same level, while the dynamics in the main group was positive (smaller areas of paresthesia, alleviated pain).

Table 1. Electrical excitability of the skin of the lower lip in zones 2 and 3 at the time of admission, corresponding with the severity of damage to IAN

\begin{tabular}{|c|c|c|c|}
\hline \multirow{2}{*}{ Zone } & \multicolumn{2}{|c|}{ Severity of IAN damage } \\
\cline { 2 - 4 } & mild & moderate & \multicolumn{2}{|c|}{ severe } \\
\hline 2 & $55 \pm 1.5 \mu \mathrm{A}$ & $109.6 \pm 3.1 \mu \mathrm{A}$ & $159.5 \pm 4.5 \mu \mathrm{A}$ \\
\hline 3 & $58 \pm 1.5 \mu \mathrm{A}$ & $121.9 \pm 3.5 \mu \mathrm{A}$ & $168.1 \pm 4.8 \mu \mathrm{A}$ \\
\hline
\end{tabular}


By the end of treatment, the patients with mild and moderate injuries to IAN had regained normal electrical excitability of the skin. Clinical symptoms of IAN damage such as numbness in the lower lip, pain during palpation of the lower lip, and the loss of sensitivity on the affected side, were gone.

In the patients with severe injuries (the main group) who completed the treatment course electrical excitability in all studied zones fell within the normal reference range. But in the control group 12 patients still had increased excitability in zones 2 and $3(45.1 \pm 3.2 \mu \mathrm{A}$ and $43.2 \pm 3.1 \mu \mathrm{A}$, respectively). Increased skin excitability was accompanied by such symptoms as numbness and tingling.

By days 32-40, the area of paresthesia in the lower lip, mouth corner, chin skin, and gums on the affected side had shrunk in 103 patients from the main group (as compared to the controls) and covered only zones 2 and 3. Because Mexicor had a positive effect on microcirculation that was visible already on day 3 of treatment: soft tissue edema on the affected side diminished in size in 74 patients.

Motivating the patients toward a healthy lifestyle was one of the most important components of the treatment plan. Our study shows that low health literacy is one of the major factors negatively affecting person's general health. The patients were encouraged to change their attitude to health care in general and diet and exercise in particular. As a result, the proportion of patients following a healthy diet increased from $13.6 \%$ to
$36.2 \%$; $30 \%$ of patients improved their sleeping habits (vs $16.1 \%$ before the study), and $23.2 \%$ (vs $12.6 \%$ before the study) became more physically active. Eleven percent of the patients gave up smoking.

\section{CONCLUSIONS}

The measurements taken on days 32-40 of treatment demonstrated that the electrical excitability of the skin had decreased in the 4 studied zones in the patients with moderate and severe injuries who had been receiving Combilipen and Mexicor.

The paresthetic area in the patients from the main group had also shrunk and covered only zones 2 and 3 at the time of measurements, while in the controls it still covered zones 1 , 2 and 3. Therefore, we conclude that Combilipen and Mexicor stimulate regeneration of the damaged nerve and alleviate clinical symptoms of IAN injuries.

Rehabilitation also included psychologic counselling aimed to motivate the patients toward a healthier lifestyle and change their attitude to medical care in general. As a result, the number of patients who started to trust medical recommendations increased by $31.2 \%$. This, in turn, led to a 2.9 -fold increase in the number of patients with IAN injuries who enjoyed a complete recovery.

\section{References}

1. Kopetskiy IS, Prityko AG, Polunina NV, Nasibullin AM. Travmatizm chelyustno-litsevoy oblasti sredi naseleniya. RMZh. 2009; 6: 3-6.

2. Celeste RK. Illegal dmg use is associated with postoperative complications in persons with mandibular fractures. J Evid Based Dent Pract. 2009; 9: 227-8.

3. Korzh GM. Diagnostika i lechenie povrezhdeniy nizhnego al'veolyarnogo nerva pri perelomakh nizhney chelyusti i stomatologicheskikh manipulyatsiyakh: avtoref [dissertatsiya]. Smolensk: 1989

4. Timofeev AA, Lesnukhin VL. Izuchenie sostoyaniya nizhnego al'veolyarnogo nerva pri povrezhdeniyakh nizhney chelyusti $v$ dinamike provodimogo lecheniya. Chast' 1. Sovremennaya stomatologiya. 2009; 3: 109-15.

5. Morozova MN, Shabliy DN, Dzhereley AA. K voprosu o diagnostike stepeni tyazhesti travmaticheskogo nevrita nizhnego al'veolyarnogo nerva. Vestnik problem biologii i meditsiny. 2013; 2 (100): 314-18.

6. Skuridina EP. Kliniko-diagnosticheskie kriterii nevralgii troynichnogo nerva [dissertatsiya]. M.: 2006.

7. Levenets AA, Grigor'yan AS. K patogenezu posttravmaticheskikh deformatsiy nizhney chelyusti rastushchego organizma. Stomatologiya. 2000; 1: 20-5.

8. Baker B, Gibbons S, Woods M. Intra-alveolar distraction osteogenesis in preparation for dental implant placement combined with orthodontic/orthognathic surgical treatment: A case report. Australian Dental Journal. 2003; 48: 65-8.

9. Kopylov AV, Sirak SV, Kopylova IA i dr. Kompleksnoe lechenie odontogennykh travm nizhnego al'veolyarnogo nerva. Sovremennye problemy nauki i obrazovaniya. 2013; 4. URL: www.science-education.ru/111-10132.

\section{Литература}

1. Копецкий И. С., Притыко А. Г., Полунина Н. В., Насибуллин А. М. Травматизм челюстно-лицевой области среди населения. РMЖ. 2009; 6: 3-6.

2. Celeste RK. Illegal dmg use is associated with postoperative

10. Gorbonos IA. Oslozhneniya pri osteosinteze perelomov nizhney chelyusti i ikh profilaktika [dissertatsiya]. Novosibirsk: 2007.

11. Bodneva SL, Puzin MN, Kiparisova ES i dr. Kopmleksnaya terapiya odontogennogo nevrita lunochkovykh nervov. Klinicheskaya nevrologiya. 2010; 1: 14-7.

12. Ivashchenko NI, Ippolitov VP. Osteosintez $\vee$ lechenii tyazhelykh sochetannykh cherepno-litsevykh travm u yunoshey. Klinicheskaya stomatologiya. 2007; 3: 56-9.

13. Jungel P. Parasthesia of infraorbital nerve following fractura of zygomatic complex. J Oral Maxillofac Surg. 1987; 16 (3): 362-7.

14. Polunin VS, Dubrovin MS, Kopetskiy IS. Mediko-sotsial'naya kharakteristika bol'nykh s povrezhdeniyami chelyustno-litsevoy oblasti. Vestnik Roszdravnadzora. 2013; 2: 46-9.

15. Kopetskiy IS, Nasibullin AM. Mediko-sotsial'naya kharakteristika bol'nykh s tyazhelymi sochetannymi povrezhdeniyami sredney zony litsa i osobennosti okazaniya im meditsinskoy pomoshchi v usloviyakh reanimatsionnogo otdeleniya. RMZh. 2012; 2: 3-7.

16. Grigoryants LA, Sirak SV, Kopylova IA, Elizarov AV. Khirurgicheskoe lechenie odontogennykh kompressionnykh travm nizhnego al'veolyarnogo nerva posle endodonticheskikh vmeshatel'stv. Endodontiya today. 2013; 4: 53-8.

17. Sirak SV. Kliniko-anatomicheskoe obosnovanie lecheniya i profilaktiki travm nizhneal'veolyarnogo nerva, vyzvannykh vyvedeniem plombirovochnogo materiala $v$ nizhnechelyustnoy kanal [dissertatsiya]. M.: 2006.

18. Belousov AE. Plasticheskaya, rekonstruktivnaya i esteticheskaya khirurgiya. SPb.: Gippokrat, 1998. 774 p.

19. Kurtoglu $Z$ et al. Effect of trapidil after crush injury to a peripheral nerve. Acta Med Okayama. 2005; 59 (2): 37-44

complications in persons with mandibular fractures. J Evid Based Dent Pract. 2009; 9: 227-8.

3. Корж Г. М. Диагностика и лечение повреждений нижнего альвеолярного нерва при переломах нижней челюсти и 
стоматологических манипуляциях [диссертация]. Смоленск: 1989.

4. Тимофеев А. А., Леснухин В. Л. Изучение состояния нижнего альвеолярного нерва при повреждениях нижней челюсти В динамике проводимого лечения. Часть 1. Современная стоматология. 2009; 3: 109-15.

5. Морозова М. Н., Шаблий Д. Н., Джерелей А. А. К вопросу о диагностике степени тяжести травматического неврита нижнего альвеолярного нерва. Вестник проблем биологии и медицины. 2013; 2 (100): 314-8.

6. Скуридина, Е. П. Клинико-диагностические критерии невралгии тройничного нерва. [диссертация]. М.: 2006.

7. Левенец А. А., Григорьян А. С. К патогенезу посттравматических деформаций нижней челюсти растущего организма. Стоматология. 2000; 1: 20-5.

8. Baker B, Gibbons S, Woods M. Intra-alveolar distraction osteogenesis in preparation fordental implant placement combined with orthodontic/orthognathic surgical treatment: $A$ case report. Australian Dental Journal. 2003; 48: 65-8.

9. Копылов А. В., Сирак С. В., Копылова И. А. и др.. Комплексное лечение одонтогенных травм нижнего альвеолярного нерва. Современные проблемы науки и образования. 2013; 4. URL: www.science-education.ru/111-10132.

10. Горбонос И. А. Осложнения при остеосинтезе переломов нижней челюсти и их профилактика [диссертация] Новосибирск: 2007

11. Боднева С. Л., Пузин М. Н., Кипарисова Е. С. Комплексная терапия одонтогенного неврита луночковых нервов. Клиническая неврология. 2010; 1: 14-7.
12. Иващенко Н. И., Ипполитов В. П. Остеосинтез в лечении тяжелых сочетанных черепно-лицевых травм у юношей. Клиническая стоматология. 2007; 3: 56-9.

13. Jungel P. Parasthesia of infraorbital nerve following fractura of zygomatic complex. J Oral Maxillofac Surg. 1987; 16 (3): 362-7.

14. Полунин В. С., Дубровин М. С., Копецкий И. С. Медикосоциальная характеристика больных с повреждениями челюстно-лицевой области. Вестник Росздравнадзора. 2013; 2: 46-9.

15. Копецкий И. С., Насибуллин А. М. Медико-социальная характеристика больных с тяжелыми сочетанными повреждениями средней зоны лица и особенности оказания им медицинской помощи в условиях реанимационного отделения. РМЖ. 2012; 2: 3-7.

16. Григорьянц Л. А. Сирак С. В., Копылова И. А., Елизаров А. В. Хирургическое лечение одонтогенных компрессионных травм нижнего альвеолярного нерва после эндодонтических вмешательств. Эндодонтия today. 2013; 4: 53-8.

17. Сирак С. В. Клинико-анатомическое обоснование лечения и профилактики травм нижнеальвеолярного нерва, вызванных выведением пломбировочного материала в нижнечелюстной канал [диссертация]. М.: 2006.

18. Белоусов А. Е. Пластическая, реконструктивная и эстетическая хирургия. СПб.: Гиппократ; 1998. 774 с.

19. Kurtoglu Z. et. al. Effect of trapidil after crush injury to a periphera nerve. Acta Med Okayama. 2005; 59 (2): 37-44. 